\title{
PENENTUAN KRITERIA ILMIAH POTENSI TUMBUHAN OBAT UNGGULAN
}

\author{
Laode Rijai \\ Kelompok Bidang Ilmu Kimia Farmasi, Fakultas Farmasi, Universitas Mulawarman, Samarinda \\ e-mail:najwankhanrjai@yahoo.co.id
}

\begin{abstract}
There is no new name for prime Medisinal plants which can be used to asses medicinal plants. Used of the term is done intuitively by decision makers of the management section or utilization of medicinal plants, which eventually became a name. The study is scientifically to determine the scientific criteria of prime medicinal plants has been done. The method used for the assessment is discussion with expert respondents using multiple methods of decision making. Respondents who used the expert academics and practitioners. Academics consists of expertise Natural Product chemistry, Natural Product Pharmaceuticals (Phamacognosy), Environmental Science, Forestry sciences, and Natural medicine industry. The result of the determination of criteria for assessment of scientific research prime plants found in five criteria (a) The diversity of usefulness / efficacy of a medicinal plant possessed (b) types of diseases can be cured by a medicinal plants (c) easy cultivation of medicinal plants (d) diversity of secondary metabolites content in a medicinal plant (e) type of organ or plant part used as medicine. The five criteria have been validated by using 9 kinds of herbs that have been deemed superior by the Indonesian Food and Drug Administration.
\end{abstract}

Key words: Scientific criteria, prime medicinal plants, study

\begin{abstract}
ABSTRAK
Istilah tumbuhan obat unggulan belum ada kriteria ilmiah yang dapat digunakan untuk menilai suatu tumbuhan obat. Penggunaan istilah tersebut dilakukan secara intuisi oleh pengambil keputusan dalam bidang pengelolaan atau pemanfaatan tumbuhan obat, yang akhirnya menjadi suatu istilah. Telah dilakukan pengkajian secara ilmiah untuk menentukan kriteria ilmiah tumbuhan obat unggulan. Metode yang digunakan untuk pengkajian tersebut adalah diskusi dengan responden ahli dengan memanfaatkan beberapa metode pengambilan keputusan. Responden ahli yang digunakan adalah akademisi dan praktisi. Akademisi terdiri dari keahlian Kimia Bahan Alam Hayati, Farmasi Bahan Alam (Farmakognosi), Ilmu Lingkungan, ilmu Kehutanan, dan pelaku industri obat alami. Hasil penelitian pengkajian penentuan kriteria ilmiah tumbuhan unggulan ditemukan lima kriteria yaitu (a) Keragaman kegunaan/khasiat yang dimiliki suatu tumbuhan obat (b) jenis penyakit yang dapat disembuhkan oleh suatu tumbuhan obat (c) kemudahan budidaya suatu tumbuhan obat (d) keragaman kandungan metabolit sekunder dalam suatu tumbuhan obat (e) jenis organ atau bagian tumbuhan yang digunakan sebagai bahan obat. Kelima kriteria tersebut telah divalidasi dengan menggunakan 9 jenis tumbuhan obat yang telah dianggap unggul oleh Badan Pengawasan Obat dan Makanan.
\end{abstract}

Kata Kunci : Kriteria ilmiah, Tumbuhan obat unggulan, pengkajian. 


\section{PENDAHULUAN}

Istilah tumbuhan obat unggulan telah digunakan oleh berbagai kalangan untuk menilai suatu tumbuhan obat yang telah terbukti memiliki khasiat untuk pengobatan. Penggunaan istilah tumbuhan obat unggulan dilakukan secara intuisi yaitu berdasarkan kekaguman akan khasiat suatu tumbuhan obat tertentu dan tumbuhan tersebut telah digunakan secara luas. Kekaguman keunggulan suatu tumbuhan obat bersumber dari data tradisional, hasil penelitian in vitro, hasil uji preklinik, dan uji klinik.

Badan Pengawasan Obat dan makanan telah menetapkan 18 jenis tumbuhan obat yang dianggap unggul karena tumbuhan obat tersebut telah digunakan sebagai bahan aktif obat alami khususnya obat yang telah masuk dalam kategori status fitofarmaka dan herbal terstandar. Status 18 jenis tumbuhan obat unggulan tersebut memberikan pengaruh nilai ekonomi yang positif sehingga masyarakat membudidayakannnya. Berdasarkan bukti tersebut, status tumbuhan obat unggulan dapat menghasilkan manfaat lingkungan dalam pengelolaannya, karena menarik perhatian masyarakat untuk melestarikannya dengan cara budidaya, akan tetapi dapat menjadi keadaan sebaliknya jika tumbuhan tersebut sukar dibudidayakan. Banyak tum-buhan obat liar yang tidak kala unggul dengan tumbuhan obat yang telah dianggap unggul oleh BPOM, namun data tumbuhan obat liar tersebut hanya berupa bukti empirik tradisional dan belum dibuktikan secara ilmiah. Mekanisme penentuan tumbuhan obat unggulan yang dianut sekarang ini memerlukan waktu yang lama untuk menetapkannya menjadi suatu tumbuhan obat unggul, sehingga dapat saja terjadi terhadap suatu tumbuhan obat ditetapkan se-bagai tumbuhan obat unggulan setelah ketersediaan di alam tumbuhan tersebut berada dalam status punah atau rawan atau genting atau jarang.

Dengan demikian diperlukan kriteria ilmiah tumbuhan obat unggulan untuk menilai tingkat keunggulan suatu tumbuhan obat. Kriteria tumbuhan obat unggulan yang diperlukan adalah suatu kriteria yang dapat digunakan untuk menilai keunggulan tumbuhan obat yang telah memiliki data-data ilmiah tentang keunggulannya dan juga dapat digunakan untuk menilai keunggulan tumbuhan obat liar yang belum memiliki bukti ilmiah tentang keunggulannya. Tujuan penggunaan kriteria tumbuhan unggulan akan berbeda terhadap tumbuhan obat liar dengan tumbuhan obat yang telah memiliki bukti ilmiah tentang khasiatnya. Penggunaan kriteria tumbuhan unggulan untuk menilai tumbuhan obat yang telah memiliki bukti ilmiah keunggulannya bertujuan untuk mempromosikan tumbuhan obat tersebut kepada para industri sehingga tumbuhan tersebut digunakan sebagai bahan aktif obat pada industri obat tersebut. Selanjutnya, penggunaan kriteria tu-mbuhan unggulan untuk menilai tumbuhan obat liar yang hanya memiliki bukti empirik tradisional tentang keunggulannya bertujuan mempromosikan tumbuhan obat tersebut kepada peneliti agar mengkaji lebih lanjut kebenaran khasiat tumbuhan obat berdasarkan data tradisional tersebut.

\section{TUJUAN PENELITIAN}

Tujuan pengkajian penentuan kriteria ilmiah tumbuhan obat unggulan adalah untuk menemukan kriteria-kriteria ilmiah tumbuhan obat unggulan yang dapat digunakan untuk menilai tumbuhan obat liar yang hanya memiliki bukti empiris tradisional dan juga terhadap tumbuhan obat yang telah memiliki bukti ilmiah. Manfaat penilaian keunggulan tumbuhan 
obat liar sebagai promosi pada peneliti untuk segera mengkaji lebih lanjut tumbuhan obat liar tersebut hingga mencapai realisasi pemanfaatan, sedangkan penilaian keunggulan terhadap tumbuhan obat yang telah memiliki bukti ilmiah tentang kegunaanya juga merupakan promosi terhadap masyarakat untuk segera dimanfaatkan.

\section{METODE}

Penelitian ini menggunakan pendekatan ahli, yaitu penggunaan responden ahli untuk merumuskan dan menetapkan bobot setiap kriteria tumbuhan obat unggulan yang ditemukan.

\section{a. Responden Ahli}

Responden ahli yang digunakan terdiri dari akademisi dan praktisi. Akademisi yaitu ahli yang berkualifikasi doktor dalam bidang yang terkait dengan substansial permasalahan, sedangkan praktisi adalah pelaku industri obat alami. Responden ahli dari akademisi adalah Kimia Bahan Alam Hayati, Farmasi Bahan Alam (Farmakognosi), ilmu Lingkungan, dan ilmu Kehutanan (konservasi sumberdaya hutan), sedangkan praktisi pelaku dalam industri obat alami di Indonesia. Jumlah responden ahli yang digunakan masingmasing 3 orang sehingga berjumlah 15 orang.

\section{b. Konsep Kriteria Tumbuhan Obat Unggulan}

Konsep kriteria tumbuhan obat unggulan diajukan peneliti kepada responden ahli. Konsep kriteria tersebut selanjutnya diverifikasi responden ahli dengan cara menyatakan pendapat terhadap konsep tersebut. Konsep yang diajukan sebagai calon kriteria tumbuhan obat unggulan adalah:
(1) Keragaman kegunaan/khasiat yang dimiliki tumbuhan obat, yaitu jumlah kegunaan tumbuhan obat untuk pengobatan

(2) Jenis penyakit yang dapat disembuhkan oleh tumbuhan obat, yaitu jenis penyakit apa saja yang dapat disembuhkan dengan tumbuhan obat tersebut

(3) Keragaman kandungan metabolit sekunder dalam tumbuhan obat, yaitu jumlah golongan metabolit sekunder yang terkandung dalam tumbuhan tersebut

(4) Bagian atau organ tumbuhan yang digunakan sebagai bahan obat, yaitu bagian tumbuhan yang digunakan sebagai obat seperti daun, akar, buah, dan lainnya

(5) Ketersediaan suatu tumbuhan obat di alam bebas, yaitu stok tumbuhan yang saat ini ada di alam bebas atau yang belum dibudidayakan

(6) Kemudahan budidaya tumbuhan obat, yaitu periode waktu yang diperlukan tumbuhan hingga tumbuhan tersebut telah dapat digunakan

\section{c. Verifikasi Konsep Kriteria}

Konsep kriteria tumbuhan obat unggulan diverifikasi kelayakannya oleh responden ahli yang telah ditentukan. Cara verifikasi konsep kriteria tumbuhan obat unggulan ditunjukkan pada Tabel 1 .

Hasil skor maksimun setiap kriteria dari 15 orang ahli 75 , sedangkan skor yang paling rendah adalah nol (0). Setiap kandidat kriteria yang diajukan dapat diterima menjadi suatu kriteria tumbuhan obat unggulan jika kriteria tersebut mendapatkan skor $\geq 60 \%$. Cara perhitungan jumlah skor yang dicapai setiap kriteria yaitu jumlah skor yang dicapai kriteria tersebut dibagi dengan total skor maksimun kemudian dikalikan $100 \%$. 


\section{Penentuan Bobot Setiap Kriteria}

Setiap kriteria tumbuhan obat unggulan yang ditemukan ditentukan bobotnya dengan jumlah bobot keseluruhan adalah 1,00 atau $100 \%$. Bobot kriteria menunjukan tingkat kualitas kriteria tersebut. Penentuan bobot kriteria menggunakan metode Eckenrode dalam Ma'ruf (2003). Karakteristik metode ini adalah perubahan urutan menjadi nilai yaitu urutan pertama dengan tingkat nilai tertinggi dan urutan kedua dengan tingkat nilai di bawahnya, dan seterusnya. Jumlah urutan diberikan tingkat pertama hingga jumlah kriteria terpilih. Teknik pemberian skor setiap urutan adalah:

- Urutan 1 mempunyai nilai $=\mathrm{k}-1$

- Urutan 2 mempunyai nilai $=\mathrm{k}-2$, Jadi nilai $=$ jumlah kriteria - urutan. Formula penentuan bobot kriteria adalah:

Tabel 1. Kuesioner verifikasi kriteria tumbuhan obat unggulan dengan responden ahli dalam bidang pemanfaatan potensi tumbuhan obat yang berkelanjutan

\begin{tabular}{|c|c|c|}
\hline No & Pertanyaan & Pilihan Jawaban \\
\hline 1 & $\begin{array}{l}\text { Kriteria yang diajukan masih perlu ditambah } \\
\text { atau dikurangi }\end{array}$ & $\begin{array}{l}\text { a. Perlu ditambah atau dikurangi } \\
\text { b. Tidak perlu }\end{array}$ \\
\hline 2 & Jika perlu, mohon ditambahkan & Kemukakan redaksinya \\
\hline 3 & $\begin{array}{l}\text { Rumusan kriteria tambaan dapat diterima } \\
\text { sebagai kriteria }\end{array}$ & a. Ya b. Tidak \\
\hline 4 & $\begin{array}{l}\text { Bagaimana pendapat anda tentang kriteria } 1 \\
\text { s/d } 6\end{array}$ & $\begin{array}{l}\text { a.sangat setuju b.setuju c.kurang setuju d.tidak } \\
\text { setuju }\end{array}$ \\
\hline
\end{tabular}

Setiap jawaban pertanyaan diberikan skor dengan rincian:

(a) Sangat setuju diberikan skor 5

(b) Setuju diberikan skor 4

(c) Kurang setuju diberikan skor 2

(d) Tidak setuju diberikan skor 0

$$
\begin{aligned}
& \% \text { Skor Kriteria }(i)=\frac{\sum_{j=1}^{n} \lambda e j}{\text { Jumlah Skor Maksimum }} \times 100 \% \\
& W_{e}=\frac{\text { dalam Ma'ruf (2003) }}{\sum_{e=1}^{k} \lambda e j \sum_{j=1}^{n} \lambda e j} \text { untuk } e=1 ; 2 ; . . . k \quad
\end{aligned}
$$

Keterangan:

$W=$ bobot setiap kriteria

$n \quad=$ jumlah expert

$k=$ jumlah kriteria

$\lambda_{e j}=$ nilai tujuan $k e \lambda$ oleh expert $k e j$ 
Tabel 2. Format Pemberian skor kriteria Keunggulan Tumbuhan Obat untuk penentuan derajat kepentingan kriteria dengan metode Eckenrode

\begin{tabular}{|c|c|c|c|c|c|c|}
\hline \multirow[b]{2}{*}{ No } & \multirow[b]{2}{*}{ Kriteria } & \multicolumn{5}{|c|}{ Skor pada Urutan } \\
\hline & & I & II & III & IV & $\mathrm{V}$ \\
\hline 1 & $\mathrm{~A}$ & & & & & \\
\hline 2 & B & & & & & \\
\hline 3 & $\mathrm{C}$ & & & & & \\
\hline 4 & D & & & & & \\
\hline 5 & E & & & & & \\
\hline 6 & $\mathrm{~F}$ & & & & & \\
\hline NILAI & & & & & & \\
\hline
\end{tabular}

Tabel 3. Contoh tumbuhan obat unggulan menurut BPOM yang digunakan untuk validasi kriteria tumbuhan obat

\begin{tabular}{lc} 
unggulan & \\
\hline No & Jenis Tumbuhan Obat \\
\hline 1 & Sambiloto (Andrographis paniculata Ness) \\
3 & Jambu biji (Psidium guajava. L) \\
4 & Jati belanda (Guazuma ulmivolia L.mk Var.tomentosa, K. schum) \\
5 & Temu lawak (Curcuma xanthorrixha, Roxb) \\
6 & Jahe merah (Zingberis officinale, Roscb, var. Rubrum) \\
7 & Kunyit (Curcuma domestica, Val) \\
8 & Mengkudu (Morinda citrifolia, L) \\
9 & Salam (Eugenia polyantha wight (Zyzygium polyantha) \\
\hline
\end{tabular}

Tabel 2. menunjukkan format pemberian skor kriteria untuk menentukan bobot setiap kriteria dengan menggunakan metode Eckenrode.

\section{c. Validasi Kriteria Tumbuhan Obat Unggulan}

Kriteria tumbuhan obat unggulan yang telah ditemukan selanjutnya dilakukan validasi yaitu mencobakan penggunaan kriteria tumbuhan obat unggulan yang telah ditemukan dengan menilai tingkat keunggulan tumbuhan obat yang selama ini telah ditetapkan Badan Pengawasan Obat dan Makanan sebagai suatu tumbuhan obat unggulan. Jika hasil penilaian tingkat keunggulan terhadap beberapa tumbuhan obat unggul tersebut menunjukkan kategori unggul atau sangat unggul, maka kriteria yang telah ditemukan dinyatakan valid. Uji validitas dilakukan terhadap 9 jenis tumbuhan obat yang telah dianggap unggul oleh Badan Pengawasan Obat dan Makanan Kementerian Kesehatan Republik Indonesia. Tumbuhan-tumbuhan tersebut ditunjukkan pada Tabel 3.

\section{e. Teknik Penggunan Kriteria}

Teknik perhitungan penggunaan kriteria tumbuhan unggulan untuk menilai tingkat keunggulan tumbuhan obat dilakukan dengan rumus berikut:

Keterangan:
TKTO
= Tingkat Keunggulan Tumbuhan Obat
TJSSKKTO = Total Jumlah Skor Semua Kriteria Keunggulan yang dicapai suatu Tumbuhan Obat
TJSMSKKTO= Total Jumlah Skor Maksimun semua Kriteria Keunggulam Tumbuhan Obat 


\section{Tingkat keunggulan potensi tumbuhan obat ditunjukkan pada Tabel 4}

Tabel 4. Skor tingkat keunggulan potensi tumbuhan obat

\begin{tabular}{llc}
\hline No & Tingkat Keunggulan & \% Pencapaian Skor \\
\hline 1 & Sangat Unggul (SU) & $90-100$ \\
2 & Unggul (U) & $60-89$ \\
3 & Cukup Unggul (CU) & $30-59$ \\
4 & Kurang Unggul (KU) & $<30$ \\
\hline
\end{tabular}

Tabel 5. Kriteria terpilih hasil diskusi dengan enam orang responden ahli sebagai kriteria tumbuhan obat unggulan khususnya untuk tumbuhan obat liar

\begin{tabular}{|c|c|c|}
\hline No & Jenis Kriteria & Keterangan \\
\hline 1 & $\begin{array}{l}\text { Keragaman khasiat atau kegunaan setiap } \\
\text { tumbuhan sebagai obat }\end{array}$ & $\begin{array}{l}\text { Makin banyak khasiat atau kegunaan suatu } \\
\text { tumbuhan obat semakin tinggi skor tumbuhan } \\
\text { obat yang dicapai pada kriteria tersebut }\end{array}$ \\
\hline 2 & $\begin{array}{l}\text { Keragaman kandungan metabolit sekunder } \\
\text { dalam setiap tumbuhan obat }\end{array}$ & $\begin{array}{l}\text { Makin banyak kelompok metabolit sekunder } \\
\text { terkandung dalam tumbuhan obat, makin tinggi } \\
\text { skor yang dicapai tumbuhan obat pada kriteria } \\
\text { tersebut }\end{array}$ \\
\hline 3 & $\begin{array}{l}\text { Jenis penyakit yang dapat disembuhkan setiap } \\
\text { tumbuhan obat }\end{array}$ & $\begin{array}{l}\text { SuatuTumbuhan obat mendapatkan skor yang } \\
\text { tinggi jika menyembuhkan penyakit penyebab } \\
\text { kematian nomor satu atau penyakit yang banyak } \\
\text { diderita masyarakat atau penyakit yang belum ada } \\
\text { obatnya }\end{array}$ \\
\hline 4 & $\begin{array}{l}\text { Organ atau bagian setiap tumbuhan yang } \\
\text { digunakan sebagai obat }\end{array}$ & $\begin{array}{l}\text { Skor kriteria keunggulan tinggi jika organ } \\
\text { tumbuhan obat yang digunakan tidak } \\
\text { mengganggu kelangsungan hidup spesies tersebut }\end{array}$ \\
\hline 5 & $\begin{array}{l}\text { Kemudahan budidaya setiap tumbuhan obat } \\
\text { (daur hidup) }\end{array}$ & $\begin{array}{l}\text { Makin singkat waktu daur hidup suatu tumbuhan } \\
\text { obat, makin tinggi skor yang dimiliki tumbuhan } \\
\text { obat pada kriteria tersebut. }\end{array}$ \\
\hline
\end{tabular}

Sumber: Diskusi ahli: 2007

Tabel 6. Hasil penilaian urutan kriteria tumbuhan obat unggulan dari hasil disekusi dengan enam orang responden ahli

\begin{tabular}{llllllll}
\hline & & \multicolumn{7}{c}{ Skor pada Urutan } \\
\cline { 3 - 8 } No & & I & II & III & IV & V \\
\hline 1 & Keragaman khasiat Tumbuhan Obat & 0 & 10 & 3 & 2 & 0 & \\
2 & Bagian tumbuhan yang behasiat obat & 0 & 6 & 7 & 1 & 1 & \\
3 & Keragaman golongam Senyawa sekunder & 0 & 0 & 10 & 3 & 2 & 0 \\
4 & Jenis khasiat obat (penyakit yang diobati) & 15 & 0 & 0 & 0 & 0 \\
5 & Kemudahan budidaya & 15 & 0 & 0 & 0 & 0 \\
\hline NILAI & 4 & 3 & 2 & 1 & 0
\end{tabular}

Sumber: penilaian ahli, 2007 
Tabel 7. Bobot derajat kepentingan (dk) setiap kriteria tumbuhan obat unggulan, dengan menggunakan metode

\begin{tabular}{clcc}
\multicolumn{1}{c}{ Eckenrode } & \multicolumn{2}{c}{ Bobot } & Rangking \\
\hline No & \multicolumn{1}{c}{ Jenis Kriteria } & 0,1775 & II \\
2 & Keragaman khasiat Tumbuhan Obat & 0,1542 & III \\
3 & Keragaman golongam metabolit sekunder & 0,1074 & IV \\
4 & Jenis khasiat obat (penyakit yang diobati) & 0,2803 & I \\
5 & Kemudahan budidaya & 0,2803 & I \\
\hline TOTAL JUMLAH BOBOT & $\mathbf{1 , 0 0 0 0}$ &
\end{tabular}

\section{HASIL PENELITIAN DAN PEM- BAHASAN}

Konsep kriteria tumbuhan unggulan yang diajukan peneliti kepada responden ahli berjumlah 6 kriteria dan selanjutnya diverifikasi oleh responden ahli terhadap enam kriteria yang dajukan tersebut. Hasil verifikasi responden ahli terhadap enam kriteria tersebut dinyatakan 5 kriteria yang dapat disetujui sebagai suatu kriteria tumbuhan obat unggulan. Lima kriteria tumbuhan obat unggulan tersebut ditunjukkan pada Tabel 5.

Kelima kriteria tumbuhan unggulan tersebut memiliki bobot yang berbeda antara satu dan lainnya. Penentuan bobot setiap kriteria ditunjukkan pada Tabel 6 dan hasil penentuan bobot tersebut ditunjukkan pada Tabel 7.

\section{a. Keragaman Khasiat Tumbuhan Obat}

Keragaman khasiat atau keragaman kegunaan suatu tumbuhan obat yang dimaksud adalah sejumlah khasiat atau kegunaan suatu tumbuhan obat digunakan sebagai bahan aktif obat. Makin banyak jenis penyakit atau kegunaan suatu tumbuhan obat, makin unggul tumbuhan obat tersebut. Karena itu keragaman khasiat atau kegunaan tumbuhan obat merupakan salah satu kriteria tumbuhan obat unggulan yang memiliki bobot relatif tinggi yaitu berada di bawah kriteria yang memiliki bobot tertitinggi yaitu jenis penyakit yang dapat disembuhkan dan kemudahan budidaya tumbuhan obat.

\section{b. Organ Tumbuhan yang Digunakan Sebagai Obat}

Organ atau bagian tumbuhan yang digunakan sebagai obat yaitu organ atau bagian tumbuhan tersebut yang digunakan sebagai bahan aktif obat. Penilaian keunggulan terkait dengan ketersediaan organ tersebut secara terus menerus dan pengaruh organ tersebut terhadap kelangsungan hidup spesies. Organ yang dimaksud adalah buah, bunga, daun, ranting atau dahan, kulit batang, batang, dan akar. Jika suatu tumbuhan obat yang berfungsi sebagai bahan aktif obat adalah akar, maka nilai keunggulan tumbuhan obat tersebut rendah karena penggunaan akar akan mempengaruhi kelangsungan hidup suatu spesies. Namun demikian jika suatu tumbuhan obat mudah dibudidayakan, maka penggunan akar tidak mempengaruhi penyediaan bahan baku sehingga pemanfaatannya berkelanjutan. Karena itu bobot kriteria tersebut hanya berada satu tingkat dari keriteria yang memiliki bobot terendah. 


\section{c. Keragaman Metabolit Sekunder dalam Tumbuhan Obat}

Metabolit sekunder adalah senyawa alami sekunder dalam hayati yang banyak berperan sebagai obat. Jika suatu tumbuhan mengandung lebih dari satu kelompok metabolit sekunder maka tumbuhan tersebut akan memiliki kegunaan yang lebih banyak terutama sebagai obat. Karena itu makin banyak kelompok metabolit sekunder dalam suatu tumbuhan obat, maka tumbuhan tersebut memiliki keunggulan. Namun demikian satu kelompok metabolit sekunder dapat saja memberikan khasiat lebih dari satu karena khasiat obat dapat saja berasal dari senyawa tunggal. Karena itu keriteria keragaman metabolit sekunder yang terkandung dalam suatu tumbuhan obat memiliki bobot paling rendah dibandingkan dengan 4 kriteria lainnya.

\section{d. Jenis Penyakit yang dapat Disembuhkan}

Suatu tumbuhan obat dikatakan unggul atau sangat unggul jika tumbuhan obat tersebut dapat menyembuhkan jenis penyakit penyebab pertama kematian di Indonesia atau penyakit yang banyak diderita masyarakat atau jenis penyakit yang belum ada obatnya. Jika suatu tumbuhan obat dapat berfungsi salah satu atau ketiga kegunaan tersebut, maka tumbuhan obat tersebut akan bernilai ekonomi tinggi dan termasuk dalam kategori unggul atau sangat unggul. Karena itu bobot kriteria jenis penyakit yang dapat disembuhkan memiliki bobot tertinggi bersama dengan kriteria kemudahan budidaya.

\section{e. Kemudahan Budidaya}

Kemudahan budidaya yaitu mudah tidaknya suatu tumbuhan obat untuk dibudidayakan. Kemudahan budidaya tersebut terkait dengan waktu daur hidup suatu tumbuhan obat yaitu waktu yang diperlukan suatu tumbuhan untuk tumbuh dari masa tanam hingga masa panen. Suatu tumbuhan obat yang mudah dibudidayakan akan berstatus unggul meskipun bagian yang digunakan adalah akar. Karena itu bobot kriteria kemudahan budidaya adalah yang tertinggi bersama dengan kriteria jenis penyakit yang dapat disembuhkan. Satu kriteria yang diajukan tidak terpilih sebagai kriteria tumbuhan obat unggulan yaitu ketersediaan tumbuhan obat pada alam bebas. Kriteria tersebut tidak terpilih sebagai kriteria tumbuhan obat unggulan karena suatu tumbuhan obat yang ketersediaannya di alam bebas rendah, tidak akan menyebabkan tumbuhan obat tersebut tidak unggul, karena jika mudah dibudidayakan maka penyedeiaan bahan baku obat dapat dilakukan secara terus menerus. Lima kriteria yang telah ditemukan dan dinyatakan sebagai kriteria tumbuhan obat unggulan, telah dilakukan uji validitas dengan cara menggunakan kriteria tersebut untuk menilai keunggulan 9 jenis tumbuhan obat yang telah dianggap unggul oleh Badan Pengawasan Obat dan Makanan Kementerian Kesehatan Republik Indonesia.

Hasil uji validitas terhadap 9 jenis tumbuhan obat unggulan tersebut menunjukkan bahwa semua tumbuhan uji coba berstatus unggul. Dengan demikian kelima kriteria tersebut dapat diterima sebagai kriteria tumbuhan obat unggulan.

\section{KESIMPULAN}

Kesimpulan penelitian ini adalah:

a. Telah ditemukan lima kriteria tumbuhan obat unggulan dengan bobot yang berbeda yang dapat digunakan untuk menilai keunggulan tumbuhan obat liar (belum dimanfaatkan) dan 
keunggulan tumbuhan obat yang telah memiliki bukti ilmiah tentang kegunaannya. Kriteria tumbuhan obat unggulan tersebut adalah (1) kemudahan budidaya (2) jenis penyakit yang dapat disembuhkan (3) keragaman kandungan metabolit sekunder (4) keragaman kegunaan atau khasiat tumbuhan obat (5) organ atau bagian tumbuhan yang digunakan sebagai obat.

b. Kriteria tumbuhan obat unggulan yang ditemukan memiliki bobot ilmiah karena dilakukan dengan metodologi ilmiah dan telah dilakukan uji validitas kriteria yang telah dirumuskan.

\section{DAFTAR PUSTAKA}

1. Marimin. 2004, Teknik dan aplikasi pengambilan keputusan kriteria majemuk. Gramedia Wirasarana Indonesia; Jakarta

2. Ma'arif, M.S.; \& Tanjung, H. 2003, TeknikTeknik Kuantitatif untuk Manajemen. Gramedia Wirasarana; Indonesia

3. Gordon, C. R; \& Arthur, A. S. 2000, Valuing Research Leads. Bioprospecting and the Concervation of Genetic Resources. Journal of Political

4. Eryatno. 1998, Ilmu Sistem: Peningkatan Mutu dan Efektivitas Manajemen. Jilid I Edisi Kedua. IPB Press; Bogor 